\title{
EST Reading Curriculum \& Instruction: An Alignment Analysis
}

\author{
Lubna Ali Mohammed \\ Department of English, Faculty of Major Languages Studies, Universiti Sains Islam Malaysia (USIM) \\ E-mail: luby_luda@yahoo.com \\ Sidek H.M (Corresponding author) \\ Department of English, Faculty of Major Languages Studies, Universiti Sains Islam Malaysia (USIM) \\ E-mail: harison@usim.edu.my
}

Doi:10.7575/aiac.alls.v.6n.1p.120

URL: http://dx.doi.org/10.7575/aiac.alls.v.6n.1p.120
Received: 23/09/2014

Accepted: 30/11/2014

\begin{abstract}
In order for a curriculum to achieve its goals, it is imperative that the curriculum is coherent at all levels. In order to determine the coherency of a curriculum, the alignment of its theoretical underpinning and the label of a curriculum is one of the aspects that can be examined. The purpose of the current study was to examine if the theoretical grounding of the Yemeni EST senior secondary curriculum is in alignment with its communicative-based curriculum label. In line with its label, the reading curriculum embedded in the EST curriculum should be developed and designed based on the Communicative Language Teaching (CLT), which should be reflected in the EST reading instructional practice. In analysing the alignment of the communicative language teaching approach in the EST senior secondary school reading curriculum, the primary focus of the analysis was on the major SLA theories and L2 reading theories and the related instructional approaches. The data for this study were collected via an ESP textbook review as well as from the observation of the EST reading classroom instruction. The findings show that the EST senior secondary reading curriculum was not developed based on the socio-cognitive and socio-cultural theories which are the grounding principles of the communicative approach. Instead, the findings show that the EST senior secondary reading curriculum was primarily developed based on the cognitive information processing theory, in which teaching instruction reflects the student as an individual information processor and the focus on teaching vocabulary and grammatical rules using reading texts in non-communicative manner.
\end{abstract}

Keywords: Communicative Approach, SLA Theories, L2 Reading Theories

\section{Introduction}

Curriculum coherence has attracted the issue of interest among researchers for many decades (e.g., Mcmahon \& Thakore, 2006; Biggs, 2003; Obanya, 2002; Anderson, 2002). In an outcomes-based curriculum, courses, modules, and programmes are planned based on the end objective, the skills and knowledge that are required to be achieved by the students at the end of the teaching programme, the term 'outcomes' is used to describe the competencies and knowledge the students have at the end of the learning program (Surgenor, 2010). Biggs (2003) in his Basic Model of an Aligned Curriculum indicates that any outcome based-curriculum is based on a consistency and coherence between many elements such as assessment, teaching strategies and intended learning outcomes in an educational programme, where the intended learning outcomes are designed first and the teaching strategies second followed by the assessment. Obanya (2002) names the curriculum elements differently as the achieved curriculum, the designed curriculum and the implemented curriculum; however he insisted that a perfect coherence must be found between them. In order to solve problems in the teaching and learning platform, consistency and coherence must be planned across the entire curriculum (Biggs, 1999; Bateman et al., 2009). The need for alignment among curriculum, instruction and assessment is a vital principle of educational practices (Biggs, 1999). In an aligned curriculum, all elements in the teaching program, the curriculum and its planned outcomes, the learning activities, the teaching methods and the assessment tasks must be associated and aligned. When the curriculum alignments have been formed, the learners achieve the maximum learning and success (Biggs, 1999).

Recent literature on curriculum development is primarily on designing a coherent curriculum to achieve the desired learning outcomes. It has been acknowledged that regardless of the particular theoretical underpinnings of every curriculum, curriculum writers accentuate the significance importance of curricular coherence (Howard, 2007). Thus, every curriculum is based on a particular theoretical orientation about language teaching and learning (Basturkman 1999, Richards and Rodgers, 2001), and as such, the consistency among a curricula components can be inferred by examining the alignment of the theoretical orientation in the designed curriculum to the implemented and achieved curriculum. 
Coherent curriculum is crucial to achieve the goals and objectives for the curriculum, which are stated in the beginning level in designing a curriculum. The theoretical underpinnings of the curriculum determine the choice of the teaching processes through which the curriculum is implemented. The teaching processes should be aligned to the processes required of the student in attaining the intended learning outcomes of the program. Educational objectives are the final qualifications that are aimed to be achieved by the student at the end of the program.

\subsection{English Language Curriculum in Yemen}

The current education system in Yemen is based on the needs of the Yemeni society in different aspects of life (The Republic of Yemen, the Parliament house, General Act for Education (45), 1992). English Language Teaching (ELT) at the secondary school level is defined and assured by the current educational system. The 3rd grade English Language curriculum is developed to support and advance the skills of the English as a foreign language (EFL) Yemeni secondary school students aiming at preparing them and providing them with the proper foreign language skills and knowledge to produce Yemeni graduates who are well prepared and equipped with all EFL skills needed for their higher education. However, the standard of English in Yemen has not been at its strong desired foothold (Ali, 2007). To date there has been little satisfaction on the students' level of proficiency in reading English. Azzan (2001 as cited in Al-Tamimi, 2006) stated that Yemeni secondary school graduates lack practical and training to read effectively.

In fact, it is becoming increasingly important to deal effectively with the learners' need in terms of reading skill in order to learn how to comprehend and interact effectively with the ideas given in the written text. Yemeni students are simply encouraged to repeat literal ideas from the text and thus unconsciously build memorization skills other than reading comprehension skills (Bamatraf, 1997 as cited in Al-Tamimi, 2006). Moreover, research has consistently shown that English reading teachers in Yemen focus on understanding word meaning and answering grammatical questions, while neglecting and skipping any reading for pleasure passages that may train them to build up comprehension skills (AlTamimi, 2006).

As mentioned Hassen (2009), recent studies (e.g., Al-amri, 2007; Mahfoodh, 2007; Al-Shamiry, 2002) have investigated the reasons behind the English language teaching and learning problems in Yemen through examining the English language curriculum of high school in Yemen for all language skills. They examined the Yemeni EFL curriculum because curriculum is the vehicle to achieve the desired educational goals of nations in which the product of each curriculum reflects the curriculum's effectiveness (Mutebi, 1996). According to Mutebi (1996, p.1):

"The effectiveness of each curriculum is determined by the performance of its products, using the curriculum aims and the nations' goals and expectations as indicators. If the performance of the curriculum products falls short of the national expectations, efforts usually made to identify the causes and problems. These may be the curriculum itself in its totality or one of its components of objectives, content, methodology or evaluation. The problem may also be identified in the implementation strategies".

Most of the studies presented above were only carried out to analyse the curriculum of the Yemeni secondary school. However, to the best of the researchers' knowledge, mere attention has been allocated to examine English for specific purposes reading curriculum, particularly English for Science and Technology (hereafter EST) for 3rd grade (senior level) of secondary school. In addition, no published research related to the Yemeni setting has examined the alignment of the theoretical grounding of the Yemeni EST senior secondary curriculum with its label as a communicative-based curriculum. Therefore, the challenges found among university students in Yemen while reading in English could be the impact of the misalignment at the theoretical underpinnings level of the curriculum. Accordingly, this paper aims at examining the alignment of the theoretical underpinning and the overarching approaches to Second Language (L2) reading instruction reflected in the Yemeni EST 3rd grade secondary school reading curriculum.

\subsection{The Communicative Language Teaching Approach (CLT) and the Yemeni EST Secondary Curriculum}

The Communicative Language Teaching Approach (CLT) is a recognized theoretical model in English language teaching today (Ozsevik, 2010). CLT classrooms should be characterised by CLT features (Williams, 1995) which requires the learner to be involved actively in the production of the L2 (Hymes, 1972). Target language classrooms have a great emphasis on the language use rather than the language knowledge and on fluency and appropriateness in the use of the target language rather than the structural correctness; while, little emphasis on error correction and explicit instruction for the language rules. In addition, in CLT classrooms, tasks and exercises that encourage a meaningful negotiation among students and students and teachers and using authentic materials take place in a formal as well as an informal environment. On the contrary to traditional approaches, in CLT approaches, a teacher acts as a facilitator while the learners are actively involved in classroom interpretation, expression and negotiation. Thus, CLT approach focuses more on the learner (Savignon, 2002).

The Yemeni EST secondary school curriculum has been identified as a communicative-based curriculum (Al-Tamimi, 2006; Hassen, 2009). The Republic of Yemen and World Bank (2010) declared that the Yemeni EFL course book, workbook and teacher's guide book of basic and secondary educational level were developed as a communicative-based curriculum. Hence, the EST reading curriculum are reflected in the interactive theory of information processing and student-centred teaching instruction, which reflect the principles of the communicative approach of the curriculum (UNESCO, 2011). In line with the label of the Yemeni EST secondary curriculum as a communicative-based curriculum, the reading curriculum embedded in the EST curriculum must be developed and designed based on the CLT approaches. As such, the socio cultural theory of Second Language Acquisition (SLA) and second language interactive 
reading theory should be reflected in the Yemeni EST reading curriculum because both theories are the platforms of the communicative approaches to language teaching (Dumessa, 2002).

Socio-cultural theory is related to Vygotsky's notion (1978) of how language can be used as a tool in meaningful interaction developing the human cognitive and higher mental function (Aimin, 2013; Matsuoka \& Evans, 2004). Socio-cultural theory emphasizes the interaction between the society, individuals and culture. This theory explains that developing the human cognitive and higher mental function is achieved through an interaction between three elements; social, cultural and biological elements. As such, the individual's language is developed from social activities requiring both cognitive and communicative skills through the mediation of the language (Aimin, 2013; Matsuoka \& Evans, 2004). Within the sociocultural framework, the learners are seen as active constructors of their own learning environment (Mitchell \& Myles, 1998).

Within L2 reading theory, the interactive theory of L2 reading came due to the limitations of L2 reading bottom-up and top-down theories (Oyetunji, 2011). The interactive reading theory posits that comprehension is considered the result of a dynamic relationship between the bottom-up and the top-down theories, between decoding and interpretation information in the text, and between reader's prior knowledge and information in the text (Lee, 2009). Basically, the interactive theory is defined as different elements being simultaneously processed in the reader's cognition to understand the text using different reading models (Redondo, 1997). Reading comprehension instruction that is based on the L2 reading interactive theory, a teacher acts as a facilitator. Engaging the students in the process of reading in an interactive manner is effective in providing the students with the skills that they will need to overcome the reading problems during their reading for content-based courses at the university level (Astika, 2004).

Based on the label of the Yemeni EFL curriculum as a communicative grounding curriculum, the socio cultural theory of second language acquisition and the interactive theory of second language reading theory should be reflected as the theoretical grounding of the curriculum. In order to achieve the targeted academic outcomes, a curriculum must be designed based on the selected theoretical grounding to guide it (Hansen, 1995). Thus, it can be assumed that the Yemeni EST 3rd grade secondary school reading curriculum was designed and developed based on the sociocultural theories of SLA and the Interactive L2 reading theory. Hence, investigating if these theories are reflected in the EST 3rd grade reading curriculum is crucial to ensure that the curriculum is coherent in terms of its theoretical underpinning.

\section{Methodology}

The purpose of the present study was to examine the alignment of the theoretical underpinning and the overarching instructional approaches to second language reading instruction reflected in the Yemeni EST 3rd grade secondary school reading curriculum. The study sought to answer the following Research Questions (RQs):

RQ1: What second language acquisition (SLA) theories and instructional approaches are reflected in the Yemeni $3^{\text {rd }}$ grade EST reading curriculum and instruction?

RQ2: What L2 reading theories and instructional approaches are reflected in Yemeni $3^{\text {rd }}$ grade EST reading curriculum and instruction?

\subsection{Theoretical Framework}

The method of analysing the theoretical underpinning and the overarching approaches to L2 reading instruction reflected in the Yemeni EST 3rd grade reading curriculum in the present study was based on a revised model of Sidek (2010) of method analysis of teaching reading, which is a revised model of Richards and Rodgers (2001). This model presents a conceptual framework for language instruction in which it proposes that at the fundamental level, language instruction can be analysed in terms of three organizational levels; Approach (represents the assumptions about the foundational theory such as the theory of second language acquisition and language learning), Design (refers to a definition of linguistic content, a specification for the selection and organization of content, and a description of the role of learner, and teaching materials), and Procedure (techniques and practices takes place in L2/FL classroom and can be analysed through teacher interview, observation for classroom activities, materials used, and feedback provided).

\subsection{Instruments}

Dumessa (2002), Rahman (2007) and Zohrabi (2013) described classroom observation sheets as a research instruments and tools. Moreover, Griffee (2012, p.105) mentioned that documents such as textbooks are data instrument in case study design. Thus, the instruments used to collect the data were the EST curriculum documents and classroom observation sheets. Past studies on analysing English language curriculum emphasized on analysing the entire materials of English language curriculum (Hassen, 2009). The materials of English for Science and Technology (EST) 3rd grade secondary school in the present study were the EST course book, EST workbook and EST 3rd grade reading classroom observation sheets.

\subsubsection{EST Course Book}

It is used by both EST teachers and learners. All the reading passages are included in this book. The EST reading passages and reading related statements were elicited from this book.

\subsubsection{EST Workbook}

It is used by the Yemeni EST learners. It includes the learning tasks for all the lessons in the course book. The reading related statements were from this book. 


\subsubsection{Classroom Observation Sheets}

For classroom observation, 2 observation sheets were used. The observation sheets contain a table to record the SLA theories and $\mathrm{L} 2$ reading theories.

\subsection{Data Collection}

Past studies that examined EFL/ESL curriculum often used content analysis method (Hassen, 2009; Heilmann \& Korte, 2010; Lie, 2001, 2007; Sidek, 2010; Xiohong, 2009). Moreover, past studies in curriculum analysis (Hassen, 2009; Lawrence, 2011) used different procedures in data collection such as questionnaire, content analysis, observation, and interview and classroom observation method to gather relevant data. Therefore, in line with the previous studies, the data of this study were collected using two methods: 1) curriculum documents review and 2) classroom observation. Hence, in this study, curriculum documents of the Yemeni English for Science and Technology (EST) 3rd grade secondary school as well as the data collected from classroom observation were reviewed.

\subsection{Procedures}

\subsubsection{Document Review Procedure}

The selected EST 3rd grade secondary school documents were reviewed to collect the data in this study. All reading related statements were collected from the course book and workbook and then were coded based on the variables in the research questions of this paper.

\subsubsection{Classroom Observation Procedure}

Classroom observations were conducted to observe the Yemeni EST 3rd grade secondary school reading teachers' teaching instruction. First of all, in the selected districts, 4 schools and 8 teachers ( 2 teachers from each school) were selected. Arrangements were made with the teachers for classroom observation. 16 EST 3rd grade reading classrooms were observed and the lessons were tape recorded with teachers' informed consent. Then, each reading lesson was transcribed verbatim. A list of reading related statements were elicited from the transcriptions and they were coded according to the variables in the two research questions. This method is considered as the most standardized technique of collecting data through observation, which can be conveniently labelled and described prior to the next measures in the data collection procedure (eTA, 2008)

For the document review, the course book and the workbook were reviewed to answer the RQs. A list of reading related statements were elicited from the course book and workbook and were coded based on the variables in the research questions of the study. Thus, data for RQ1 and RQ2 were collected from EST course book, EST workbook and EST reading classroom transcripts.

\subsection{Data Analysis}

RQ1: Second Language Acquisition (SLA) theories and instructional approaches reflected in the Yemeni 3rd grade EST reading curriculum and instruction

SLA theories and its instructional approaches that are reflected in the Yemeni EST 3rd grade reading curriculum were analysed by inferring the different related statements in 3rd grade EST secondary school curriculum in reference to the three main SLA theories, namely, behaviourism structuralism theory, cognitive theory of information processing, and socio-cognitive and socio-cultural theory and their related instructional approaches. The L2 instructional approaches such as the Grammar Translation Method and Audio Lingual Method, which emphasize on allocating major part of reading class to teach the grammatical rules by utilizing the mother language in translating new vocabulary in the text (Nakatsugawa, 2009) reflect in the behaviourism/structuralism theory. Reading statements that account on practicing different mental activities in the readers mind apart from any grammatical rule inclusion or communicative activities reflect the cognitive theory of information processing, while L2 instructional approaches such as content based and task based instructional approaches which based on the communicative language teaching approach principles reflect the socio-cognitive/socio-cultural theory.

RQ2: L2 reading theories and instructional approaches reflected in Yemeni 3rd grade EST reading curriculum and instruction

L2 reading theories and its instructional approaches that are reflected in Yemeni 3rd grade EST reading curriculum were analysed by inferring the different related statements in 3rd grade EST secondary school curriculum in reference to the three main L2 reading theories, namely, Bottom-Up theories, Top-Down theories, and Interactive theories. All the reading statements were extracted from the selected documents and coded according to these three major L2 reading theories.

\section{Findings and Discussion}

RQ1\&2: Second Language Acquisition (SLA) theories / L2 reading theories and instructional approaches reflected in the Yemeni 3 rd grade EST reading curriculum and instruction

Findings of RQ1, SLA theories, share equivalent percentages with findings of RQ2, L2 reading theories. The equivalent findings of RQ1 and RQ2 might be because the bottom-up reading theories are grounded in similar principles as the behaviourism/structuralism theories; the top-down reading theories are grounded in similar principles as the cognitive theory and the interactive theories are grounded in similar principles as the socio-cognitive and socio-cultural theory. 
The findings of RQ 1 and RQ2 on SLA theories and L2 reading theories and related instructional approaches reflected in the Yemeni EST 3rd grade reading curriculum for secondary school in Yemen are presented in Table 1.

Table 1. L2 reading theory and instructional approaches in the selected documents

\begin{tabular}{|c|c|c|c|}
\hline $\begin{array}{c}\text { SLA Theories \& } \\
\text { Related Instructional } \\
\text { Approaches / }\end{array}$ & $\begin{array}{c}\text { Structuralism } \\
\text { Theory } \\
\text { (GTM \& ALM) }\end{array}$ & $\begin{array}{c}\text { Cognitive Information } \\
\text { Processing } \\
\text { Theory }\end{array}$ & $\begin{array}{l}\text { Socio-Cognitive \& Socio- } \\
\text { Cultural Theory } \\
\text { (CBI \&TBI) }\end{array}$ \\
\hline Documents & $\begin{array}{l}\text { Bottom-up L2 } \\
\text { Reading Theory } \\
\text { (GTRI) \% }\end{array}$ & $\begin{array}{c}\text { Top-Down L2 Reading } \\
\text { Theory } \\
\text { (NIWLI) \% }\end{array}$ & $\begin{array}{l}\text { Interactive L2 Reading Theory } \\
\text { (CBI \&TBI) \% }\end{array}$ \\
\hline EST Course Book & 19.5 & 61 & 19.5 \\
\hline EST Workbook & 23 & 58 & 19 \\
\hline EST CO & 36 & 54 & 10 \\
\hline Overall Percentages & 28 & 57 & 15 \\
\hline
\end{tabular}

Key: $\%=$ Percentage of L2 Reading Theories and Corresponding Instructional Approaches, GTM= Grammar Translation method, $\mathrm{ALM}=$ Audio Lingual Method, $\mathrm{CBI}=$ Content Based Instruction, $\mathrm{TBI}=$ Task Based Instruction, GTRI= Grammar Translation Reading Instruction, NIWLI= Non-Interactive Whole Language Instruction.

The findings show that the cognitive theory of information processing and L2 top-down reading theory were the most frequently reflected theories in reading related statements $(57 \%$ each) followed by the structuralism theory and L2 bottom-up reading theory ( $28 \%$ each) and the socio-cognitive/socio-cultural theory and L2 interactive reading theory $(15 \%$ each). However, the majority of the reading-related statements in the EST course book, workbook and reading classroom observation were reflected in the socio-cognitive/socio-cultural theory and L2 interactive theory with the least percentage $(19.5 \%, 19 \%$ and $10 \%$ respectively). The least percentage of socio-cognitive/socio-cultural and L2 interactive reading theory ( $10 \%$ for each theory) was emerged from the reading classroom instruction compared to the cognitive processing and L2 top-down reading theory (54\% for each theory) and the structuralism and L2 bottom-up reading theory ( $36 \%$ for each theory).

On the other hand, in both EST workbook and reading classroom observation, the structuralism theory and the L2 bottom-up reading theory were the most frequently reflected in reading-related statements $(23 \%$ in the workbook and $36 \%$ in the course book) after the socio-cognitive / socio-cultural theory and L2 interactive reading theory (19\% in the workbook and $10 \%$ in the course book). However, in the EST course book, the structuralism theory and the L2 bottomup reading theory and the socio-cognitive/socio-cultural theory and L2 interactive reading theory were represented equally $(19.5 \%$ each). Such findings were found to be contradicting with the claim that the EST 3rd grade curriculum was designed in alignment with the communicative language teaching approach and its instructional methods. Instead, the results of the current study show that the EST 3rd grade reading curriculum was primarily developed based on the cognitive theory of information processing, in which reading comprehension instruction reflects the learner role as an individual information processor.

The reflection of the non-communicative instructional approaches in the EST work book (23\%) and classroom practices $(36 \%)$ are more than the communicative instructional approaches $(19 \%$ in the work book and $10 \%$ in classroom practices). Such findings indicate that the non-communicative approach of teaching English language in the Yemeni secondary schools is prevalent. Thus, the claim of shifting the instructional mode of the English language in the Yemeni setting from non-communicative to communicative instructional approach was not evidenced in the findings of the current study.

The findings from classroom observation suggest that the Yemeni EST 3rd grade reading teachers' instructional implementation primarily reflects the non-interactive top down reading theory rather than the interactive reading theory. Reading tasks in the classrooms frequently reflected the bottom-up reading theory $(36 \%)$ and top-down reading theory (54\%) with little reflection of the interactive reading theory $(10 \%)$. These findings are in line with the findings of previous studies (e.g., Na'ama, 2011; Al-Ahdal, 2010), which reported that in the Yemeni secondary school English classroom the dominant focus of implementations is on teaching grammatical rules in a non-communicative manner. The data from classroom observations provide evidence that the Yemeni teachers still strictly adhere to the noncommunicative method of explaining the text explicitly to students instead of discussing the text as it is advocated by the communicative language teaching approach.

In short, the results of the SLA theories and L2 reading theories analyses showed that the Yemeni EST 3rd grade reading curriculum was not developed based on the communicative approach. The findings of the present study are 
consistent with the findings of Murshed (2002 as cited in Hassen, 2009), who reported that the Yemeni English language curriculum does not adopt the socio-cognitive / socio-cultural theories of SLA and interactive L2 reading theories. As it is today, EST teachers in the Yemeni secondary schools continue to teach reading in a noncommunicative manner, which is a misalignment with the communicative label of the curriculum. If the curriculum was grounded in the CLT approach, the socio-cognitive / socio-cultural theory and L2 reading interactive theory would be significantly evidenced in curriculum documents and the reading comprehension instructional implementation level. Such reflection of the non-communicative instructional practices in the Yemeni EST reading classrooms could highly be explained to accommodate the pressure to drill students to perform well in examinations due to the examinationoriented educational system in the Yemeni setting. However, the non-communicative instructional approach could be less effective in assisting the students to use language in real life situations; and in case of reading, it might result in students with poor reading skill (Gudepu, 2013).

Thus, the findings of this study indicate that the reading tasks in the 3rd grade reading curriculum reflect the top-down L2 reading theory. Processing the text information using top-down L2 reading theory is the theoretical foundation of the non-interactive whole language approach of L2 reading instruction, which according to the results seems to be widely practiced by the Yemeni EST 3rd grade reading teachers. Without the inclusion of the communicative interaction and taking into account the reading context, the reading tasks in the curriculum seems to greatly suffer from lack of communicative features that are necessary for reading comprehension (Sidek, 2010). The findings of this study were found to be congruent with the findings of past studies in the Yemeni setting (e.g., Na'ama, 2011; Al-Ahdal, 2010; Hassen, 2009).

The results of the previously mentioned-studies are in favour of the view that the Yemeni English Language curriculum, EFL /EST, is theoretically lacking for its practical side of the communicative approach. In addition, Rababah (2005) found that although the English language curricula in most Arabic countries are claimed to be grounded in the CLT approach, the teaching practices in the Yemeni classrooms are more inclined to non-communicative methods where in reading contexts the learners only play the role of passive information processors. For example, in the EST reading instructional implementation in the current study, the teachers highly emphasized on the teaching the meaning of new vocabulary in isolated from the text. Moreover, while the learners were reading aloud, the teachers only focused on correcting the students' pronunciation of the words. This finding is in line with Azzan's (2001) findings of his study in Yemen.

Results from reading classroom observation provide evidence of the GTM and non-interactive cognitive method. The teachers instructed the students to directly express the meaning of new vocabulary in a non-interactive context. The teachers in GTM only teach the learners the meaning of the new vocabulary explicitly isolated from the context (Gough, 1972 as cited in Alsamadani, 2011). Researchers such as Pugazhenthi \& Phil (2012), Larsen-Freeman (2000) and CelceMurcia (1991) highlighted the failure of GTM in developing the learners' communicative competence as the communicative language teaching approach does (Canale \& Swain, 1980).

In addition, most of the reading classroom instructional time was allocated for teaching students de-contextualized vocabulary via translating them into mother tongue. This technique was not found to be in line with socio-cognitive and socio-cultural theories of SLA and interactive L2 reading theory that focus on using text-based discussion to clarify the vocabulary meanings. Hence, the findings of this study indicate that there is a misalignment between the EST 3rd grade curriculum label as a communicative curriculum and what the curriculum stipulates and promotes in the teaching of EST reading comprehension. According to previous studies (Al-Fatimi, 2009; Al-Mansoori, 2008; Al-Refa'ai, 2001) in the Yemeni setting the Yemeni English language classrooms were primarily teacher-centred classrooms, which is not in line with the CLT approach.

\section{Conclusion and Recommendations}

The current study is an explorative case study aims at analysing the overarching approaches to second language reading instruction reflected in the Yemeni EST 3rd grade secondary school reading curriculum in order to find out the alignment of the curriculum with its current communicative label. The Yemeni EFL curriculum, which EST 3rd grade secondary school reading curriculum is part of it is still claimed to be firmly based on the communicative approach to language learning and teaching (O’Neil et al., 1999). However, the findings of the current study show that EST 3rd grade secondary school reading curriculum is primarily based on the non-communicative approaches to language learning and teaching. Hence, it is crucial for the Yemeni EST 3rd grade secondary school curriculum to be revised to align with the CLT approach as the curriculum is labelled. This can be done by integrating the CLT features in the curriculum in a holistic manner. In doing so, the EST 3rd grade secondary school reading curriculum has to be designed based on the socio-cognitive and socio-cultural theories, which are the grounding principles of the CLT approach. Based on the findings from classroom observation, it is recommended that the Yemini MoE to conduct circular workshops and conferences for the Yemeni educationalists and schools' teachers to update them with the latest teaching approaches and to clarify any ambiguity about English classroom practices, which might take place in the field of the English language teaching. So, teachers would understand better about the CLT and its characteristics as well as they would know that grammar and vocabulary should not be taught explicitly in communicative classrooms. Teachers also will know about SLA theories and L2 reading theories. 


\section{References}

Aimin, L. (2013). The study of second language acquisition under socio-cultural theory. American Journal of Educational Research, 1(5).

Al-Ahdal, A. A. M. H. (2010). ELT in Yemen and India - The need for remedial measures. Language in India, 10. Al-Fatimi, Y. S. (2009). Investigating the Problems Face Teaching Translation Subjects at the Colleges of Education, Aden University. Unpublished master thesis, Aden University, Yemen.

Al-Mansoori, A. (2008). Reasons behind poor achievements in English by the students of scientific departments at Aden college of Education from the view point of teachers and students. Unpublished master thesis in Education, Aden University, Yemen.

Al-Refa'ai, O. Y. (2001). A study of the Reasons of Students' low Academic Achievement in English Language at Aden College of Education. Aden University, Yemen. Magazine of Aden College of Education, 3.

Alsamadani, H. A. (2011). The effects of the 3-2-1 reading strategy on EFL reading comprehension. English Language Teaching, 4.

Al-Tamimi, N. O. M. (2006). The effect of direct reading strategy instruction on students' reading comprehension, metacognitive strategy, and reading attitudes among eleventh grade students in Yemen. . Doctor of Philosophy, University Sains Malaysia, Malaysia. Retrieved from http://eprints.usm.my/9535/1/THE_EFFECT_OF_DIRECT_READING_STRATEGY_INSTRCTION_ON_STUDEN S\%E2\%80\%99_READING_COMPREHENSION,_METACOGNITIVE_STRATEGY_AWARENESS,_AND_READ NG_ATTITUDES_AMONG_ELEVENTH_GRADE_STUDENTS_IN_YEMEN.pdf.

Ali, S. E. (2007). Problems and Prospects of English. South Asian Language Review, XVII(2), 39-48.

Astika, G. (2004). A Task-based Approach to Reading English for Specialized Purposes. EA Journal, 22.

Basturkman, H. (1999). A content analysis of ELT textbook blurbs: Reflections of theory-in-use. RELC Journal, 301(1), 18-38.

Bateman, D., aylor, S., Janik, E., \& Logan, A. (2009). Curriculum coherence and student success. Pédagogie collégiale, $22(5), 8-18$.

Biggs, J. (1999). Teaching for quality learning at university. Society for Research into Higher Education / Open University Press.

Canale, M., \& Swain, M. (1980). Theoretical bases of communicative approaches to second language teaching and testing. Applied Linguistics, 1(1), 1-47.

Celce-Murcia, M. (1999). Teaching English as a Second or Foreign Language (2nd Ed.). Boston, Massachusetts: Heinle \& Heinle Publishers.

Dumessa, M. (2002). An investigation of English language teachers' reading lesson presentation in terms of the new course book for grade nine in some selected government secondary schools in Addis Ababa. Master of Arts, Addis Ababa University, Addis Ababa. Retrieved from:etd.aau.edu.et/dspace/bitstream/.../616/1/Melkamu\%20Dumessa.pdf. eTA (Producer). (2008). Evaluation Briefs: Data collection methods for program evaluation:Observation 16. Retrieved from http://www.cdc.gov/healthyyouth/evaluation/pdf/brief16.pdf.

Griffee, D. T. (2012). An introduction to second language research methods: Design and data Retrieved from http://www.tesl-ej.org/pdf/ej60/sl_research_methods.pdf.

Gudepu, M. D. (2013). Applications of Communicative Language Teaching Techniques in Reading Classes: A Special Focus on Junior Colleges in Telangana Region (India). World Journal of English Language 3(2).

Hansen, R. E. (1995). Five principles for guiding curriculum development practice: The case of technological teacher education. Journal of Industrial Teacher Education, 32(2), 30-50. Hassen, M. M. N. (2009). A critical study of crescent English course for secondary stage in Yemen. Doctor of Philosophy University of Pune, India.

Heilmann, G., \& Korte, W. B. (2010). The Role of Creativity and Innovation in School Curricula in the EU27- A content analysis of curricula documents. European Commission: Institute for Prospective Technological Studies. JRC Technical Notes.

Hymes, D. H. (1972). On Communicative Competence. In J. B. Pride \& J. Holmes (Eds.), Sociolinguistics. Selected Readings: Harmondsworth: Penguin, pp. 269-293.(Part 2). 
Larsen-Freeman, D., \& Long, M. A. i. t. s. 1. a. r. (1991). An introduction to second language acquisition research. England: Longman.

Lawrence, W. P. W. (2011). Textbook evaluation: A framework for evaluating the fitness of the Hong Kong new secondary school (NSS) curriculum. Master of Arts, City University of HongKong, Hong Kong. Retrieved from: http://www.asian-efl-journal.com/Thesis/Thesis-Wong.pdf.

Lee, C. (2009). Studies on Reading Strategies and Teaching Literary Works: Interactive Model in Reader's Theater. Da-Yeh University General Education Journal (大葉大學通識教育學報) (3), 181-191.

Lie, A. (2001). Multicultural issues in the 1994 English curriculum in Indonesian senior high schools. In W. Renandya \& N. Sunga (Eds.), Language curriculum and instruction in multicultural societies. Singapore: SEAMEO RELC, Anthology 42.

Lie, A. (2007). Education Policy and EFL curriculum in Indonesia: between the commitment to competence and the quest for higher test scores. TEFLIN Journal, 18(1).

Matsuoka, R., \& Evans, D. R. (2004). Socio-cognitive approach in second language acquisition research.

(国立看護大学校研究紀要) National College ofNursing, Japan, 3(1).

Mcmahon, T., \& Thakore, H. (2006). Achieving constructive alignment: Putting outcomes first. The Quality of Higher Education(3).

Mitchell, R., \& Myles, F. (1998). Second language learning theories. London:Arnold.

Mutebi, P. M.-. (1996). An Analysis of the Primary Education Curriculum in Uganda Including a Framework for a Primary Education Curriculum Renewal: UNESCO.

Na'ama, A. (2011). An analysis of errors made by Yemeni university students in the English consonant-clusters system. Damascus University Journal, 27.

Nakatsugawa, M. (2009). Bridging the Gap: A Communicative Grammar-Translation Approach. Barrel - Otaru University of Commerce Academic Collections Retrieved from http://hdl.handle.net/10252/2787.

O’Neil, T., Snow, P., \& Peacock, R. (1999). English Course for Yemen: Teacher's Book 6: Grant Publishing Limited for the Ministry of Education. Republic of Yemen.

Oyetunji, C. O. (2011). The effect of reading strategy instruction on L2 teacher trainees' performance. Master of Arts, University of south Africa. Retrieved from uir.unisa.ac.za/xmlui/bitstream/.../dissertation_oyetunji_co.pdf?...1. Ozsevik, Z. (2010). The Use of Communicative Language Teaching (CLT): Turkish EFL Teachers' Perceived Difficulties in Implementing CLT in Turkey. Master of Arts, University of Illinois, Urbana-Champaign. Retrieved from https://ideals.illinois.edu/bitstream/handle/2142/16211/Ozsevik_Zekariya.pdf?sequence=2

Pugazhenthi, V., \& Phil, M. (2012). The Role of English Teacher in Language Learning, Teaching and Assessment. Language in India, 12.

Rababah, G. (2005). Communication problems facing arab learners of English. Journal of Language and Learning, 3. Rahman, M. H. (2007). An evaluation of the teaching of reading skills of English in Bangladesh. Master in English, University of Rajshahi, Rajshahi, Bangladesh. Retreived from: http://www.asian efljournal.com/Thesis/ThesisRahman.pdf.

Redondo, M. (1997). Reading models in foreign language teaching. Revista Alicantina de Estudios Ingleses, 10, 139161.

Richards, J., \& Rodgers, T. (2001). Approaches and methods in language teaching. Cambridge: Cambridge University Press.

The Republic of Yemen, the Parliament house, General Act for Education (45). (1992, Feb.1993). Magazine of Democracy, p. 26.

Savignon, S. J. (2002). Communicative Language Teaching: Linguistic Theory and Classroom Practice. In S. J. Savignon. (Ed.), Interpreting communicative language teaching (pp. 1-27). New Haven \& London: Yale University Press.

Sidek, H. M. (2010). An analysis of the EFL secondary reading curriculum in Malaysia: approaches to reading and preparation for higher education. Doctor of Philosophy, University of Pittsburgh. 
Surgenor, P. (2010). Teaching toolkit: Planning a teaching session. From UCD teaching and learning/Resources.

Retreived from: http://www.ucd.ie/t4cms/UCDTLT0022.pdf.

UNESCO. (2011). World Data on Education 2010 / 2011. International Bureau of Education Retrieved from:

http://www.ibe.unesco.org/fileadmin/user_upload/Publications/WDE/2010/pdfversions/Yemen.df.

Williams, J. (1995). Focus on form on communicative language teaching: Research findings and the classroom teacher.

TESOL Journal, 4(4), 12-16.

Xiohong, Z. (2009). A Great Leap Forward: EFL curriculum, globalization and reconstructionism - A case study in North East China. Doctor of Philosophy, University of Ballarat, Australia. Retrieved from: mpra.ub.uni muenchen.de/30542/1/the_great_leap_forwrd_citatiom.

Zohrabi, M. (2013). Mixed Method Research: Instruments, Validity, Reliability and Reporting Findings. Theory and Practice in Language Studies, 3(2), 254-262. 